\title{
The Why, What, Where of social work: A personal reflection on the social work role over a thirty-year period
}

\section{Pam Smith}

Pam Smith is a wife, mother, grandmother, sister, aunt and still a daughter. She is also a social worker of 30 years. Each one of these roles is precious to her. The first two thirds of her social work career were spent at the Department of Social Welfare, Child Youth and Family, and the last third at Presbyterian Support Southland, a non-government organisation. During these years she studied extramurally at Massey University to gain her BA sociology, DipSocSci in social policy and social work and MPhil in social work.

\section{Abstract}

As the Aotearoa New Zealand Association of Social Workers celebrates its 50th anniversary it is timely to reflect on our personal and professional journeys. I present my reflections and then I consider why others may enter the profession and what literature tells us. I conclude with an encouragement for others. The 'what' and 'where' I briefly touch on but leave as a challenge for others to explore.

\section{Introduction}

This is an unremarkable story. There are many who share similar stories and indeed have been in social work a great many more years than my 30. The purpose, therefore, is to encourage you to pause and reflect on the why, what and where of social work and your own social work journey. Reflecting can be revealing and also painful, but from the learning we gain, we move forward humbler, wiser and hopefully with some degree of satisfaction.

\section{Background}

As I reflect on 30 years in social work I wonder when I actually became a social worker. Was it when I commenced my studies or when I entered paid employment? When I was a child growing up on a farm in a rural community the question was often asked of me, 'What do you want to be when you grow up?' For me it was initially a farmer's wife. I saw this as a worthwhile role. I regarded it as a partnership and of equal worth. It never entered my head, or indeed anyone else's at that time, that I could go farming in my own right! The division of gender roles was firmly entrenched during that period in Aotearoa New Zealand (Phillips, 1996; James \& Saville-Smith, 1989). Feminism was an unheard of word and concept in the 1950s in rural Southland. However, I soon realised that there were more options, so choices for me extended to school teaching or nursing. Office work was not an option as my young mind regarded it as mundane and subservient! School teaching was a strong contender especially when the sole teacher at the little country school supported this choice and allowed me to assist with the infant teaching at various times. 
However, life took many turns and it was office work that I ended up in when I entered the paid workforce. Six years later and I swapped that for the role of wife and fulltime mother. Playcentre involvement instilled in me the desire to learn and grow both as a mother but also as an individual. This experience within the centre, parent helping, supervising, working alongside other parents and watching our children grow, assisting with parent education and in time at management level both locally and nationally, enabled me to grow as an individual and gain a thirst for further knowledge. How many other women in the 1960s and 1970s had their roots in Playcentre, and the philosophy of growing alongside your children, and then moved on to public roles? Research shows evidence of this personal growth and the contribution to communities following Playcentre involvement and participation (Powell, 2005).

Once my children all commenced school, the local Education Department pre-school advisor asked me if I was interested in studying for the Otago University Certificate in Social Work at its local outpost at Southland Polytechnic. To enrol, one had to be nominated and then attend an interview panel for acceptance on to the two-year course. Attendance at tutorials on a Friday afternoon was necessary. The idea of social work was new to me. I had no experience of social work or social workers. It was not part of my life experience. I duly enrolled and was accepted on the course that commenced my journey into social work.

My first placement was at the Social Welfare Department, which again was a revelation to me, and then my second placement was in the community supporting residents through the 1984 Southland flood, which I found satisfying. The following year, with the Certificate duly completed, I enrolled in the Human Development paper extramurally at Massey University. The intention was to study while at home, one paper a year, to satisfy my ongoing thirst for knowledge. In May that year I was contacted by the manager of the Social Welfare Department asking me to work part-time to cover for a social worker who was on sick leave. I accepted and this developed into a permanent position. Thus commenced my 30-year career in social work.

My 17 years in statutory work was a huge learning curve for me. These were the years of the bi-cultural awakening, 1980s, the re-structuring of the public service (has it ever stopped?), and the huge advance in the professionalism of the industry. In 1993, Jenny Shipley, the then Minister of Social Welfare, announced that all social workers within the Children and Young Persons Service had to become qualified, and thus commenced an internal competency process and support for study (NZ Children and Young Persons Service, 1993). Many like myself, took this opportunity to gain their qualifications. However, I was one of the fortunate few that completed this process. It was very time consuming and, therefore, was not viable for workers with full caseloads. It took me a year to compile my portfolio and present for the panel interview, which took the whole day. The ANZASW competency was included in this process.

\section{The Why}

So what led me down this pathway? Why social work as a career? Was it destiny or something more mundane as a gentle progression down life's pathway with decisions based on interests and random choices? I was always interested and cared about people and 
remembered names and details. My two earlier-stated options of possible careers included teaching and nursing. All of these would be regarded as being in the 'helping professions'.

My journey into social work has led me to contemplate how others enter the profession. Readings and discussions showed that over the years those who entered social work did so as it was a 'calling or a cause' (Muller, 1994). It was regarded as similar to nursing in that it was seen as a helping profession, a vocation. Humanitarian or Christian beliefs were often the driving force behind those who entered these vocations (Dearsley, 2000; Ritchie, 2008). In the early days of the profession, often the position evolved from a person volunteering to 'help out' and then acquiring the position of social worker on a formal or informal basis. Eventually a title and/or description of the position was established, which gave the worker an identity within their workplace. This identity progressed as they identified with other workers within their social work profession and they became part of a larger body (McCreary, 1994).

There is limited research available on the reason why social workers chose their profession. Articles can be found on personal accounts, but there is a paucity of published literature. Waterman (2002) examined personality types and explanations for how these impacted on the choice of social work as a career. He explained that idealist personality types with intuitive/ feeling strengths were more likely to choose social work as a career than other personality types.

Various studies and surveys have been conducted within statutory social work over the years. A comparison of studies was conducted on the role of the social worker within Britain and New Zealand (Uttley, 1981). This was an early study and, therefore, may have little relevance on the situation of social workers today.

Cameron and Wilson-Salt (1995) interviewed workers within Child Youth and Family on their experiences that were influenced by their expectations. Smith (2001) referred to a questionnaire used to examine social workers' expectations and aspirations of their statutory social work role. This study suggested that, 'there has been a shift in initial attitudes among social workers, from expecting to carry out an enabling, supporting role, to experiencing a more controlling role' (Smith 2001, p. 24).

None of these studies actually addressed the reason why social workers chose social work. Further research is required to examine what was behind the choices made by persons entering social work and whether the aspirations of those who enter the profession are met within both statutory and non-statutory social work. Research is also required into whether professional membership of the Aotearoa New Zealand Association of Social Workers, ANZASW, and being registered has assisted social workers to define their role and place within their profession and the benefits thereof.

\section{The What}

So what has social work meant to me over the years? Initially it was an opportunity to be challenged and gain new skills and knowledge. Then it became a cause and belief that I had something to contribute to the families I cared about. This gaining and giving has continued, with the balance fluctuating throughout time. I consider myself to now be in the twilight 
of my career. Does one ever give up being a social worker or does it become part of you? I believe the latter. The skills and knowledge are always stirred to want to contribute or make a comment in some way. I have loved the mentoring role with new social workers; to support them in their learning and see their development over the years has been extremely rewarding.

There are times when I consider that I have achieved outcomes for the families not because of policies, but in spite of policies. I experience frustration at policy makers who don't consider the relevance of policies on families and the implications of these policies. Policies impact on families as to how they manage their daily lives. The resources and supports available are as a result of economic, social and political decisions made at the national level. These filter down and determine the quality of families' existence. 'Social policy concerns the way in which society meets its collective responsibilities by enhancing human development and advancing social well-being' (Shirley, 1990, p. 132).

Poverty in Aotearoa New Zealand is a major concern (Children's Commissioner, 2012). Exclusion from life necessities due to lack of finances is defined in the broad definition of poverty. However, social exclusion impacts on quality of life too and is described as, 'effectively denying formal participatory access through the process of officially restricting people as citizens' (Shannon \& Young, 2004, p. 63). Aotearoa New Zealand is part of a global environment. With this comes a mix of cultures. As social workers we 'take into account individualised differences and the cultural and social context of the clients situation' (ANZASW, 2008, p. 15). In order to ensure that we practise competently we need the support of policy makers to adequately meet the physical, emotional and social needs of all our families.

It does not help when legislation is passed that impinges on historic and inherent practices of both Treaty partners. The child and family are regarded as the core of both cultures yet we see a decreasing devaluation of both. Economic decisions are made by governments of the day that impact negatively on the relationship between parent and child. We also cannot deny that Aotearoa New Zealand has an appalling child abuse record (Children's Commissioner, 2013). We have a lot of work to do in this area.

Policy decision making also extends to the social worker's employers and the cumbersome funding and accountability processes that have been established and required to be carried out by the workers. This is reflected in articles addressing government contracting and the impact on community accountability (Aimers \& Walker, 2008; Shannon \& Walker, 2006). These processes can overwhelm and take away from practice work with families.

I have been told that I am passionate and irritating. Passionate as I have spoken strongly about policies and procedures and their effect on the families, and irritating as I may continue to address my concerns. However, pearls are developed out of irritations so these attributes can also be used positively when advocating for families. This involves ensuring that the mission statement/ charter and philosophies of the agency are constantly before all workers, then applying these to achieve change for your families. These two attributes are necessary in social work. We are the thorn in the side of the decision makers when it comes to achieving positive outcomes. We sometimes need to be the irritation that continues to be heard until changes occur or commitments are made. These practices can be carried out within the standards of our profession that leaves all parties intact. 
On my office wall are two quotes.

To practise without theory is to sail on uncharted seas. Theory without practice is not to set sail at all (Susser, 1968).

The ability to understand the underpinning of theory to practice and to apply within social work is a gradual progression. It is a process that can be frustrating at times, but then becomes an enlightenment that affirms the beauty of social work and how it is a shared process between client and worker and validates the work done. The second quote:

We shall not cease from exploration, and the end of all our exploring will be to arrive where we started and know the place for the first time (Elliot, 1942).

Reflective practice is the mainstay of social work. New reflections on past experiences help us to build upon our knowledge. We are continually learning and growing in our role within our team. We do not work on our own, but with the support and input from others; the managers / supervisors who have given guidance, the peers who have provided support, and those whom we have mentored.

I have experienced tragedy within my social work role. Two social workers who I have mentored lost their lives in separate car accidents. I cannot reflect on my social work journey without memory of them. They were two women with characteristics and skills that impacted positively on their social work families. Sandra and Michelle who were once part of 'the team' are now fondly remembered. We use the supports and supervision available to deal with these instances to ensure that we care for ourselves to enable us to continue professionally in our role.

\section{The Where}

Where do we choose to work the social work role? Do we apply for positions in social work based on the fit with our skills and attributes, the job description and the types of families we will work with, or do we choose based on remuneration and challenge? Whatever reason we choose, ultimately the level of job satisfaction will decide whether we leave or whether we stay.

Statutory social work has its own challenges. Dearsley (2000) posed the question as to whether it is actually social work. Others have stated that the involuntary client is a difficult client for a social worker to work with (Hay, Franklin \& Hardyment, 2012). Working with mandated clients means that, amongst other things, one has to be skilled in engagement techniques and be resilient. Whether these attributes are natural abilities or skills to learn, some workers will never achieve them and therefore are not suited to statutory work. (Hay et al, 2012). Statutory social workers find that they are balancing many dichotomies; child centered versus family decision making, social change versus social control, creativity versus accountability, practice driven versus outcome driven and many more.

Non-statutory work allows the worker to be more creative in utilising the range of social work theories and models of practice. Unfortunately, with funding becoming more difficult to access, securing government contracts becomes necessary. With this come prescriptive accountability demands that are very time consuming. 'If organisations become more focused 
on their relationship with the state, at the expense of their community relationships, they risk overlooking a core part of their identity and purpose,' (Aimers \& Walker, 2008, p. 14). Agencies have to continually check their mission statements and charters to ensure that their philosophies are not diluted by the demands of contractual obligations and accountability. However, working with families and their achievements in non-statutory work will win over any frustrations experienced within organisational requirements.

\section{Conclusion}

In this reflective piece, I have considered why we enter social work, what it means to us and where we would find employment in our profession. As we move forward for the next years in our social work journey we can only do so knowing where we have come from. The future is yet ours to see. The challenge to all workers is to take time and pause, consider this and why you are in the profession, what led you to it and where you want to go.

\section{References}

Aimers, J., \& Walker, P. (2008). Is community accountability being overlooked as a result of government-third sector partnering in New Zealand? Social Work Review, XX: 14-24.

Aotearoa New Zealand Association of Social Workers, Inc. (2008). Practice standards.

Beddoe, L., \& Hyslop, I. (2003). Building on the high hard ground. Social Work Now, 24: 31-37.

Cameron, S., \& Wilson-Salt, A. (1995). The summary of the report: The experience of social workers working in the area of care and protection under the Children, Young Person and their Families Act (1989). Social Work Review, V11(2).

Children's Commission. (2013). Expert Advisory Group on solutions to child poverty. Solutions to child poverty in New Zealand: Evidence for action. Retrieved from www.occ.org.nz.

Dearsley, P. (2000). Statutory social work (but is it really social work?). Social Work Review, VX11 (2).

Elliot, T.S. (1942). Little Gidding. Four Quartets. US: Harcourt.

Hay, K., Franklin, L., \& Hardyment, A. (2012). From student to employee: A conversation about transition and readiness for practice in a statutory social work organization. Social Work Now, 50: 2-9.

James, B., \& Saville-Smith, K. (1989). Gender, culture and power. Auckland: Oxford University Press.

Jones, A., \& May, J. (1992). Working in human service organisations. Cheshire: Longman.

McCreary, J.R. (1994). Keynote address to 1964 Conference. Social Work Review, V1 (4): 4-6.

Muller, P. (1994). For young E old. Invercargill: Presbyterian Support Services Southland.

NZ Children and Young Persons Service. (1993). Competency programme.

Phillips, J. (1996). A man's country? The image of the Pakeha male - a history. Auckland: Penguin Books.

Powell, K. (2005). The effect of adult Playcentre participation on the creation of social capital in local communities - report to the New Zealand Playcentre Federation. Palmerston North: Massey University.

Reporting Domestic Family Violence. Retrieved from www.areyouokay.org.nz.

Ritchie, J.E. (2008) The relation of the university to the profession of social work. Social Work Review, XX (2).

Shannon, P., \& Young, S. (2004). Solving social problems: Southern perspectives. Victoria: Dunmore Press.

Shannon, P., \& Walker, P. (2006). Community development and control in a state-local partnership in Aotearoa New Zealand. Community Development Journal, 41, 506-520.

Shirley, I. (1990). Social Policy. In P. Spoonley, D. Pearson, \& I. Shirley (Eds), New Zealand Society. Palmerston North: Dunmore Press.

Smith, P. (2001). Statutory social work: A study of workers' expectations and realisations. Social Work Review V X111(4), 22-24.

Susser, M.(1968). Cited in P. Hardiker, \& M. Baker, Towards social theory for social work. In J. Lishman (Ed). Handbook of theory for practice teachers in social work. London: Jessica Kingsley.

Uttley, S. (1981). Why social work? A comparison of British and New Zealand Studies. British Journal of Social Work, VII: 329-340.

Waterman, B. T. (2002). Motivation for choosing social service as a career. Retrieved from www.bedrugfree.ne. 